\title{
Role of Apolipoprotein E-containing Lipoproteins
}

\section{in Abetalipoproteinemia}

\author{
Conrad B. Blum, Richard J. Deckelbaum, Larry D. Witte, Alan R. Tall, and \\ JoSEPh CoRNICELli, Arteriosclerosis Research Center and Department of \\ Medicine, College of Physicians \& Surgeons of Columbia University, New \\ York 10032; Pediatric Gastroenterology Unit, Hadassah University Hospital, \\ Jerusalem, Israel
}

\begin{abstract}
A B S T R A CT Detailed studies of apolipoprotein E (apoE)-containing lipoproteins in abetalipoproteinemia have been performed in an attempt to resolve the apparent paradox of a suppressed low density lipoprotein (LDL) receptor pathway in the absence of apoB-containing lipoproteins. It was hypothesized that apoE-containing high density lipoproteins (HDL) in abetalipoproteinemia might functionally substitute for LDL in regulation of cholesterol metabolism in these patients.
\end{abstract}

The mean ( \pm standard deviation) plasma concentration of apoE in nine patients with abetalipoproteinemia was $44.8 \pm 8.2 \mu \mathrm{g} / \mathrm{ml}$, slightly higher than the corresponding value for a group of $\mathbf{5 0}$ normal volunteers, $36.3 \pm 11 \mu \mathrm{g} / \mathrm{ml}$. Fractionation of plasma lipoproteins by agarose column chromatography or by ultracentrifugation indicated that in abetalipoproteinemia, plasma apoE was restricted to a subfraction of HDL. This was in contrast to the results obtained with plasma from 30 normal volunteers, in whom apoE was distributed between very low density lipoproteins (VLDL) and HDL. Consequently, the mean apoE content of HDL in abetalipoproteinemia $(44.8 \mu \mathrm{g} / \mathrm{ml})$ was more than twice that found in the normal volunteers $(20.3 \mu \mathrm{g} / \mathrm{ml})$.

ApoE-rich and apoE-poor subfractions of $\mathrm{HDL}_{2}$ were isolated by heparin-agarose affinity chromatography. ApoE comprised a mean of $81 \%$ of the protein mass of the apoE-rich subfraction. Compared with the apoE-poor subfraction, the apoE-rich $\mathrm{HDL}_{2}$ was of larger mean particle diameter $(141 \pm 7$ vs. $115 \pm 15 \AA)$ and had a higher ratio of total cholesterol/protein $(1.01 \pm 0.11$ vs. $0.63 \pm 0.14)$.

Plasma and HDL fractions from three patients were studied with respect to their ability to compete with ${ }^{125} \mathrm{I}-\mathrm{LDL}$ in specific binding to receptors on cultured

Received for publication 16 November 1981 and in revised form 18 August 1982. human fibroblasts. The binding activity of plasma from patients (per milligram of protein) was about half that of plasma from normal volunteers. All binding activity in the patients' plasma was found to reside in the HDL fraction. The binding activity of the patients' HDL (on a total protein basis) was intermediate between that of normal HDL and normal LDL. However, the large differences in binding between patients' HDL and normal HDL entirely disappeared when data were expressed in terms of the apoE content of these lipoproteins. This suggested that the binding activity was restricted to that subfraction of HDL particles that contain apoE. These apoE-rich HDL particles had calculated binding potencies per milligram of protein 10-25 times that of normal LDL. Direct binding studies using ${ }^{125} \mathrm{I}$-apoE-rich $\mathrm{HDL}_{2}$ and ${ }^{125} \mathrm{I}$ apoE-poor $\mathrm{HDL}_{2}$, confirmed the suggestion that binding is restricted to the subfraction of HDL particles containing apoE. The apoE-rich $\mathrm{HDL}_{2}$ were found to be very potent inhibitors of 3-hydroxy-3-methyl-glutaryl coenzyme A reductase activity in cultured fibroblasts, providing direct evidence of the ability of these lipoproteins to regulate cholesterol metabolism.

On the basis of binding potencies of apoE-rich HDL, apoE concentrations, and the composition of apoE-rich HDL, it could be calculated that apoE-rich HDL in abetalipoproteinemia have a capacity to deliver cholesterol to tissues via the LDL receptor pathway equivalent to an LDL concentration of $50-150 \mathrm{mg} / \mathrm{dl}$ of cholesterol. Thus, these apoE-rich lipoproteins are capable of producing the suppression of cholesterol synthesis and LDL receptor activity previously observed in abetalipoproteinemia.

\section{INTRODUCTION}

Abetalipoproteinemia is a rare genetic disease characterized by extreme hypocholesterolemia and hypotriglyceridemia, fat malabsorption, neuromuscular and 
retinal degeneration, and acanthocytosis. The biochemical hallmark of this disease is complete absence of apolipoprotein B (apoB) ${ }^{1}$ which leads to an absence of all apoB-containing lipoproteins, namely, chylomicrons, very low density lipoproteins (VLDL), and low density lipoproteins (LDL) (1).

Brown and Goldstein (2) have established a major role for LDL, which contains apoB as its sole protein component, in the feedback regulation of cholesterol biosynthesis via the LDL receptor pathway. Thus, it had been predicted that in abetalipoproteinemia the LDL receptor pathway would be completely derepressed (3-6). Such derepression would be evidenced by rapid rates of cholesterol biosynthesis, high concentrations of LDL receptors on cell surfaces, high levels of 3-hydroxy-3-methyl-glutaryl coenzyme A (HMG CoA) reductase, and low levels of acylcoenzyme A acyltransferase (ACAT). However, several laboratories have presented data to indicate that the LDL receptor pathway is not derepressed and that total endogenous cholesterol synthesis is not excessive in abetalipoproteinemia (3-7).

This report describes an attempt to resolve the apparent paradox of a repressed LDL receptor pathway in the absence of apoB-containing lipoproteins in abetalipoproteinemia. Because of the considerable evidence that apoE can interact with the same cell surface receptor as LDL (8-11), thereby delivering lipoprotein cholesterol to cells, it seemed possible that lipoproteins containing apoE might functionally substitute for apoB-containing lipoproteins in abetalipoproteinemia. To test this hypothesis, we have performed detailed studies of the lipoproteins containing apoE in abetalipoproteinemia and of their potential role in regulation of lipoprotein metabolism.

Some of the findings presented here have previously appeared in abstract form (12).

\section{METHODS}

\section{Subjects}

Nine patients with abetalipoproteinemia were studied (Table I). All had acanthocytosis, malabsorption, and other typical clinical findings of abetalipoproteinemia. They ranged in age from 1 to $30 \mathrm{yr}$. Plasma cholesterol and triglyceride levels averaged $( \pm S D) 32 \pm 8 \mathrm{mg} / \mathrm{dl}$ and $7 \pm 3 \mathrm{mg} / \mathrm{dl}$, respectively. No apoB was detectable by radioimmunoassay (RIA) in the plasma of any of the nine patients. The patients' parents had normal plasma cholesterol and triglyceride concentrations, excluding the possibility that some of the patients may have had homozygous hypobetalipoproteinemia rather than abetalipoproteinemia (1). The extremely low

${ }^{1}$ Abbreviations used in this paper: apoA-I, apoA-II, apoB, apoE, apolipoprotein A-I, A-II, B, and E, respectively; HMG CoA reductase, 3-hydroxy-3-methyl-glutaryl coenzyme A reductase.
TABLE I

Subjects with Abetalipoproteinemia

\begin{tabular}{ccccc}
\hline Subject no. & Age & Sex & Cholesterol & Triglycerides \\
\hline & yr & & \multicolumn{3}{c}{$m g / d l$} \\
1 & 21 & F & 41 & 13 \\
2 & 30 & M & 45 & 4 \\
3 & 29 & F & 35 & 5 \\
4 & 2 & M & 29 & 5 \\
5 & 4 & F & 28 & 7 \\
6 & 4 & M & 30 & 9 \\
7 & 2 & M & 20 & 4 \\
8 & 1 & F & 26 & 2 \\
9 & 1 & M & 31 & 10 \\
Mean & & & & \\
\hline
\end{tabular}

plasma triglyceride levels and the complete absence of immunoreactive apoB excluded normotriglyceridemic abetalipoproteinemia (13).

The normal volunteers comprised 50 persons who were selected without prior knowledge of their plasma lipid levels. They were healthy at the time of sampling, and they ranged in age from 22 to $62 \mathrm{yr}$.

\section{RIA of apolipoproteins A-I, A-II, and E}

The procedure for double-antibody RIA of apoE has been described in detail (14). In brief, standards or unknowns were preincubated overnight in $50 \mathrm{mM}$ Na phosphate, 100 $\mathrm{mM} \mathrm{NaCl}, 0.02 \% \mathrm{Na}$ azide, $50 \mathrm{mM} \mathrm{Na}$ decyl sulfate, $\mathrm{pH}$ 7.4. The assay was performed in the presence of a final concentration of $5 \mathrm{mM} \mathrm{Na}$ decyl sulfate. The within assay coefficient of variation was $9 \%$ and the coefficient of variation for systematic between assay variability was $3 \%$.

ApoA-I and apoA-II RIA were performed similarly, except that specific antisera for apoA-I or apoA-II replaced the antiserum for apoE, and radioiodinated apoA-I or apoA-II replaced radioiodinated apoE. Within and between assay coefficients of variation were 10.6 and $9.0 \%$ for apoA-I, and 5.0 and $4.4 \%$ for apoA-II.

\section{Fractionation of plasma lipoproteins}

Agarose column chromatography. Whole plasma (1-2 $\mathrm{ml}$ ) was applied to a $1.2 \times 100-\mathrm{cm}$ column of $6 \%$ agarose (Bio-Gel A5M, Bio-Rad Laboratories, Richmond, CA) and was eluted with a solution of $0.2 \mathrm{M} \mathrm{NaCl}, 1 \mathrm{mM}$ EDTA, 2 $\mathrm{mM} \mathrm{Na}$ phosphate, $0.02 \% \mathrm{Na}$ azide, $\mathrm{pH}$ 7.4. Some plasma samples underwent a single freezing and thawing before chromatography. These samples yielded identical results to those obtained from material chromatographed within $7 \mathrm{~d}$ of venipuncture, which had never been frozen.

Preparative ultracentrifugation. Aliquots of plasma (never frozen) were adjusted to $1.063,1.125$, and $1.21 \mathrm{~g} / \mathrm{ml}$ densities. Each aliquot underwent a single ultracentrifugation at $4^{\circ} \mathrm{C}$ and $40,000 \mathrm{rpm}$ in a Beckman 40.3 rotor in a Beckman L2-65B ultracentrifuge (Beckman Instruments, Inc., Spinco Div., Palo Alto, CA). The aliquot at $1.063 \mathrm{~g} / \mathrm{ml}$ was centrifuged for $18 \mathrm{~h}$; the aliquots at 1.125 and $1.21 \mathrm{~g} /$ $\mathrm{ml}$ were centrifuged for $48 \mathrm{~h}$. Top and bottom fractions were separated by tube slicing. ApoE in these fractions was mea- 
sured by RIA, and the distribution of apoE in density ranges was determined by difference.

Heparin-agarose affinity chromatography. Heparin-agarose affinity chromatography was used to fractionate the $\mathrm{HDL}_{2}(d<1.125 \mathrm{~g} / \mathrm{ml}$ lipoproteins) from three patients with abetalipoproteinemia. For these studies, in which lipoprotein composition was measured, $\mathrm{Na} p$-chloromercuriphenylsulfonate $(2 \mathrm{mM})$ was added to the blood immediately after venipuncture to inhibit the enzyme lecithin cholesterol acyltransferase. These samples were never frozen. Heparin-agarose affinity chromatography of $\mathrm{HDL}_{2}$ was performed in a column containing $10 \mathrm{ml}$ of Sepharose CL-4B to which was bound $\sim 100 \mathrm{mg}$ of heparin (Fisher Scientific Co., Pittsburgh, PA) (14). Lipoproteins were applied to the column in a solution of $5 \mathrm{mM} \mathrm{Na}$ phosphate, $0.02 \% \mathrm{Na}$ azide, $\mathrm{pH}$ 7.4. The column was washed with $100 \mathrm{ml}$ of the same buffer, and apoE-rich lipoproteins were then eluted with a solution of $5 \mathrm{mM} \mathrm{Na}$ phosphate, $500 \mathrm{mM} \mathrm{NaCl}, 0.02 \% \mathrm{Na}$ azide, pH 7.4.

\section{Studies of binding to LDL receptors}

The ability of plasma and lipoprotein fractions to compete with ${ }^{125}$ I-L.DL in binding to fibroblasts was determined as previously described $(15,16)$. Normal human skin fibroblasts were grown as monolayers in tissue culture plates (15). Cells obtained from confluent stock cultures by dissociation with $0.05 \%$ trypsin $/ 0.02 \%$ EDTA were seeded into $35-\mathrm{mm}$ petri dishes at $4 \times 10^{4}$ cells in fresh stock culture medium (containing $10 \%$ fetal calf serum). On day 5 , when the cells were in a late logarithmic phase of cell growth, the monolayers were washed once with Dulbecco's-modified Eagle's medium containing $2 \mathrm{mg}$ of bovine serum albumin $/ \mathrm{ml}$. Medium containing fetal calf lipoprotein-deficient serum $(5 \mathrm{mg}$ protein/ml) was then added. Fetal calf lipoprotein-deficient serum was prepared by ultracentrifugation as the $d>1.215$ $\mathrm{g} / \mathrm{ml}$ fraction. The cells were incubated for an additional $48 \mathrm{~h}$ and then used in assays that test the ability of lipoproteins to compete for binding to $\mathrm{LDL}$ receptors. LDL, $(d=1.019-1.050 \mathrm{~g} / \mathrm{ml})$ was radioiodinated by a modification of the ICL procedure of McFarlane $(17,18) .{ }^{125}$ I-LIJI, binding was measured at $4^{\circ} \mathrm{C}$ as specific cell-surface binding releasable by dextran sulfate. Competition curves were generated by studying ${ }^{125}$ I-LDL binding in the presence of increasing concentrations of plasma or lipoprotein fractions.

Direct binding of radioiodinated apoE-rich and apoE-poor $\mathrm{HDL}_{2}$ was assessed at $37^{\circ} \mathrm{C}(16)$. ApoE-rich and apoE-poor subfractions of $\mathrm{HDL}_{2}$ were isolated by heparin-agarose affinity chromatography as described above. Aliquots of these subfractions were then radioiodinated by a modification of the iodine monochloride method of McFarlane $(17,18)$. After incubation of the cells with ${ }^{125} \mathrm{I}$-apoE-rich or ${ }^{125} \mathrm{I}$-a poEpoor $\mathrm{HDL}_{2}$ at $37^{\circ} \mathrm{C}$ for $5 \mathrm{~h}$, the cells were cooled to $4^{\circ} \mathrm{C}$ and the medium removed from each monolayer. The cell monolayers were extensively washed, and ${ }^{125} I$-lipoprotein cell surface binding was determined by measuring the radioactivity released from the cells by dextran sulfate.

\section{HMG CoA reductase activity}

To determine the ability of apoE-rich and apoE-poor $\mathrm{HDL}_{2}$ from patients with abetalipoproteinemia to regulate the activity of HMG CoA reductase in cultured human fibroblasts, several concentrations of these lipoproteins or of normal LDL were incubated with cultured human fibroblasts for $8 \mathrm{~h}$ at $37^{\circ} \mathrm{C}$. The medium was then removed and the monolayers were washed once with iced $0.15 \mathrm{M} \mathrm{NaCl}$,
$50 \mathrm{mM}$ tris $\mathrm{HCl}, \mathrm{pH} 7.4$. The cells were then scraped into $1 \mathrm{ml}$ of the same buffer and centrifuged in a Beckman microfuge. The buffer was then aspirated and the cell pellets frozen in liquid $\mathrm{N}_{2}$ until HMC; CoA reductase was measured.

HMG CoA reductase activity was assayed according to the method of Beg et al. (19). The assay measured the formation of $\left[{ }^{14} \mathrm{C}\right]$ mevalonate from $\left[{ }^{14} \mathrm{C}\right] \mathrm{HMG}$; CoA during incubations of cell extracts in the presence of $2.5 \mathrm{mM1} \mathrm{NADPH}, 150 \mu \mathrm{M}$ $\left[{ }^{14} \mathrm{C}\right] \mathrm{HMG}$ CoA, $10 \mathrm{mM}$ dithiothreitol, and $3.75 \mathrm{mM}$ EDTA. The reaction was carried out in a total volume of $100 \mu \mathrm{l}$ in $\mathrm{K}$ phosphate buffer $(0.1 \mathrm{M}, \mathrm{pH} 7.4)$ for $60 \mathrm{~min}$ at $37^{\circ} \mathrm{C}$. The reaction was terminated by addition of $20 \mu \mathrm{l}$ of $5 \mathrm{~N} \mathrm{HCl}$, and $\left[{ }^{3} \mathrm{H}\right]$ mevalonolactone was added as an internal standard to monitor the recovery of the product. The reaction product (mevalonic acid), converted to its lactone derivative, was separated from substrate by ion exchange chromatography on BioRex 5 resin, (Bio-Rad Laboratories), and assayed for radioactivity.

\section{Electron microscopy}

Before electron microscopy, samples were dialyzed against four changes of distilled water adjusted to pH 7.0 by addition of $\mathrm{NH}_{4} \mathrm{OH}$. Electron microscopy was performed on a Hitachi llc electron microscope (Hitachi l.td., Tokyo, Japan) operated at $75 \mathrm{kV}$. Dilute samples $(0.2$ to $0.5 \mathrm{mg} / \mathrm{ml}$ lipoprotein) were applied to carbon-coated Formvar-Cu grids for $\sim 1$ min, then negatively stained with $2 \%$ phosphotungstate, pH 6.8 for $20 \mathrm{~s}$. Electron micrographs were obtained under observer-blinded conditions, selecting areas where particles were not confluent. Electron micrographs were taken at $\times 67,000$ magnification. Particles were sized directly from randomly chosen areas of negatives of electron micrographs, using a magnifying eye piece with a reticle. Nonspherical particles were not used for this analysis. To determine the effects of temperature on particle morphology, lipoprotein solutions were warmed to $45^{\circ} \mathrm{C}$; for $1 \mathrm{~min}$, then applied to grids that had been placed on Parafilm floating in a water bath maintained at $45^{\circ} \mathrm{C}$. These samples were compared with preparations made at $25^{\circ} \mathrm{C}$.

\section{Analytical methods}

Sodium dodecyl sulfate (SDS) polyacrylamide gel electrophoresis was performed in gels containing $6 \%$ acrylamide, $0.5 \%$ methylene bisacrylamide using a previously described continuous buffer system (14). The gels were stained by the method of Weber and Osborne (20).

Protein was measured by the method of Lowry et al. (21), using bovine serum albumin as standard. Total cholesterol in extracts of agarose column fractions and in extracts of lipoprotein fractions was measured by the method of Chiamori and Henry (22). Free and esterified cholesterol in apoErich and apoE-poor subfractions of $\mathrm{HDL}_{2}$ were measured by gas-liquid chromatography; triglyceride in subfractions was measured by quantitative thin-layer chromatography; phospholipid in subfractions was measured by the method of Bartlett (23). The total cholesterol and triglyceride concentrations in plasma were measured using Technicon $\Lambda A-I$ methodology (Technicon Instruments Corp., Tarrytown, NY) $(24,25)$.

\section{RESULTS}

Plasma apoE concentration. The concentrations of apoE in the plasma of the nine patients with abetali- 
poproteinemia are given in Table II. The mean \pm SD apoE concentration of $44.8 \pm 8.2 \mu \mathrm{g} / \mathrm{ml}$ was significantly greater than the mean \pm SD of $36.3 \pm 11.1 \mu \mathrm{g} / \mathrm{ml}$ for a group of 50 normal volunteers $(P<0.025)$. However, the distribution of plasma total apoE levels in the two groups did overlap considerably; seven of the nine patients had values below the 90th percentile of the normals' distribution $(50 \mu \mathrm{g} / \mathrm{ml})$, and $20 \%$ of the normals had values exceeding the mean for the patients with abetalipoproteinemia. The three adult patients (No. 1-3) had similar plasma apoE levels to those of the six children with abetalipoproteinemia. Therefore, the single adult control group can be used to show that total plasma apoE concentrations in patients with abetalipoproteinemia are not subnormal.

Distribution of apoE among lipoproteins. Whole plasma from each of seven different patients with abetalipoproteinemia was fractionated by $6 \%$ agarose column chromatography yielding a single symmetrical peak of apoE immunoreactivity (Fig. 1, lower panel). This slightly preceded the single peak of cholesterol in the column eluate and was located where very large particles of normal HDL elute from this same column. This pattern was in sharp contrast to that seen in plasma samples from 30 normal volunteers (Fig. 1, upper panel) in which two major peaks of apoE immunoreactivity were invariably apparent: a first peak corresponded to VLDL and a second peak corresponded in elution volume to large HDL particles. The peaks of apoE and cholesterol in patients' plasma eluted slightly earlier than the HDL peaks of apoE and cholesterol in normal plasma; this indicated a somewhat larger mean particle size of the lipoproteins in the corresponding fractions from patients with abetalipoproteinemia. In fresh plasma from normal volunteers or from patients with abetalipoproteinemia, all apoE eluted from the column associated with lipoproteins.

Ultracentrifugation demonstrated a lipoprotein distribution of apoE analogous to that seen with column chromatography (Table II). A mean of $69.3 \%$ of plasma apoE was found in the $1.063-1.125 \mathrm{~g} / \mathrm{ml}$ density range in abetalipoproteinemia, compared with $23.9 \%$ in normal volunteers. Even more striking was the finding that only $5.6 \%$ of plasma apoE was found in the $d<1.063 \mathrm{~g} / \mathrm{ml}$ density range; this compared with $38.4 \%$ in this combined VLDL-LDL density range in normal volunteers. It was also of interest that the portion of apoE found in the $d>1.21 \mathrm{~g} / \mathrm{ml}$ fraction after ultracentrifugation was much smaller in the patients with abetalipoproteinemia $(7.6 \pm 4.2 \%)$ than in the normal volunteers $(27.3 \pm 6.0 \%)(P<0.001)$.

The observation that in abetalipoproteinemia plasma apoE is localized to a subfraction of HDL is strengthened by the qualitative agreement of two fundamentally different techniques of fractionation, gel filtration and preparative ultracentrifugation. Since all of the apoE in the plasma of these patients was associated

TABLE II

Lipoprotein Density Distribution of ApoE

\begin{tabular}{|c|c|c|c|c|c|}
\hline \multirow[b]{2}{*}{ Patient no. } & \multirow{2}{*}{$\begin{array}{c}\text { Plasma } \\
\text { apoE }\end{array}$} & \multicolumn{4}{|c|}{ Percent distribution of apoE in density ranges } \\
\hline & & $d<1.063$ & $1.063-1.125$ & $1.125-1.21$ & $d>1.21$ \\
\hline & $\mu g / m l$ & \multicolumn{4}{|c|}{$g / m l$} \\
\hline 1 & 33.3 & 5.0 & 65.3 & 23.7 & 6.0 \\
\hline 2 & 49.6 & 7.8 & 65.2 & 24.5 & 2.5 \\
\hline 3 & 43.6 & 5.9 & 69.0 & 13.4 & 11.7 \\
\hline$\bullet 4$ & 36.6 & 5.9 & 72.4 & 9.1 & 12.5 \\
\hline 5 & 37.6 & 5.0 & 73.8 & 17.8 & 3.4 \\
\hline 6 & 40.9 & 4.1 & 75.7 & 20.9 & 9.3 \\
\hline 7 & 51.6 & - & - & - & - \\
\hline 8 & 55.4 & - & - & - & - \\
\hline 9 & 54.3 & - & - & - & - \\
\hline Mean & 44.8 & 5.6 & 69.3 & 18.2 & 7.6 \\
\hline SD & 8.2 & 1.3 & 3.8 & 6.1 & 4.2 \\
\hline £Normal volunteers & 36.3 & 38.4 & 23.9 & 10.4 & 27.3 \\
\hline SD & 11.1 & 16.1 & 13.0 & 5.7 & 6.0 \\
\hline
\end{tabular}

- For this patient, the sample centrifuged at $1.063 \mathrm{~g} / \mathrm{ml}$ was lost. Distribution $\sim 1.063$ $\mathrm{g} / \mathrm{ml}$ was assumed to be the same as the mean distribution for the other five patients in whom lipoprotein density distributions were measured. The reported SD for $d<$ $1.063 \mathrm{~g} / \mathrm{ml}$ and for $d=1.063-1.125 \mathrm{~g} / \mathrm{ml}$ exclude this patient.

$\ddagger n=50$ for plasma apoE concentration; $n=9$ for lipoprotein density distribution. 

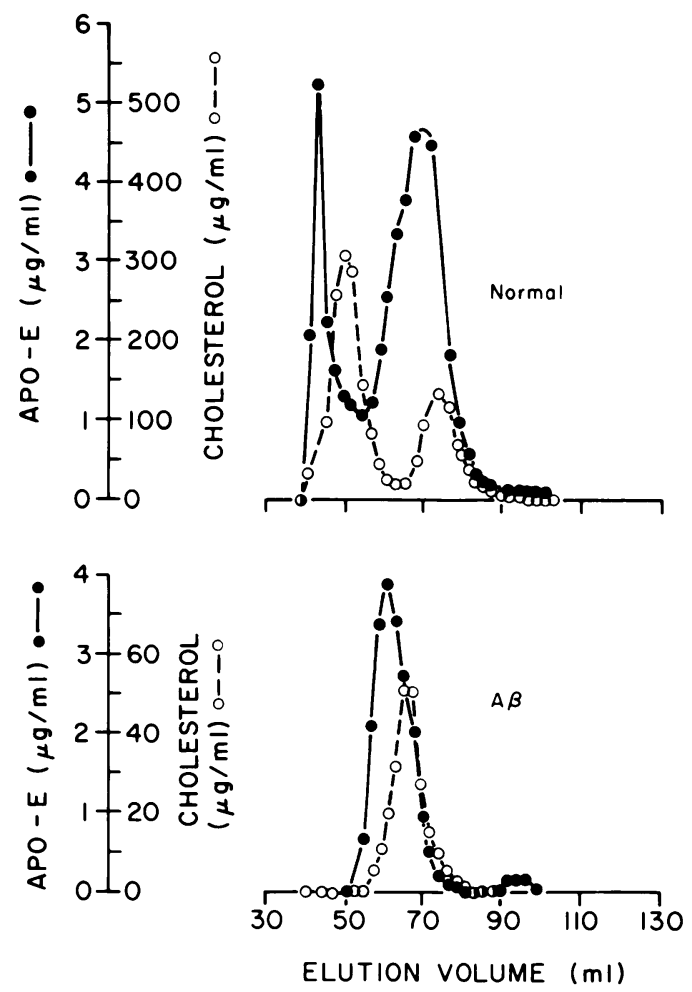

Figure l Agarose column chromatography of plasma. Plasma from a normal volunteer (above) and from patient 2 (below) were applied to a $1.0 \times 100-\mathrm{cm}$ column of $6 \%$ agarose and were eluted with $0.2 \mathrm{M} \mathrm{NaCl}, 1 \mathrm{mM}$ EDTA, 2 $\mathrm{mM} \mathrm{Na}$ phosphate, $0.02 \% \mathrm{Na}$ azide, $\mathrm{pH} 7.4$. Similar patterns to that shown in the upper panel were obtained in chromatography of samples from 30 different normal volunteers, and similar patterns to that shown in the lower panel were obtained in chromatography of samples from patients 1-7.

with HDL, the concentration of apoE in HDL must approximate the total plasma concentration of apoE, $44.8 \pm 8.2 \mu \mathrm{g} / \mathrm{ml}$. Agarose column chromatography of plasma from 30 normal volunteers indicated a mean \pm SD concentration of $20.3 \pm 6.8 \mu \mathrm{g} / \mathrm{ml}$ for apoE in the HDL fraction of normal plasma. Thus, although the plasma concentration of apoE in these patients is not very different from that in normal volunteers, the concentration of apoE in HDL of patients with abetalipoproteinemia is more than twice the concentration of apoE in HDL in normal volunteers.

Preparation and characterization of apoE-rich $H D L_{2}$. ApoE-rich $\mathrm{HDL}_{2}$ and apoE-poor $\mathrm{HDL}_{2}$ were separated from each other by heparin-agarose affinity chromatography of the $d<1.125 \mathrm{~g} / \mathrm{ml}$ fraction of plasma from patients $2,3,4$, and 6 . SDS gels of the two fractions of $\mathrm{HDL}_{2}$ obtained from patient 2 are shown in Fig. 2. The fraction retained by the column and eluted with $0.5 \mathrm{M} \mathrm{NaCl}$ (gels 1 and 3) is seen to be truly rich in apoE. The fraction not retained by the column (gels 2 and 4) is seen to contain apoA-I as its major apoprotein. Total recovery of immunoassayable apoE from plasma through the heparin affinity chromatography step averaged 59\%. The $41 \%$ total loss of apoE occurred as follows: $5 \%$ in ultracentrifugation, $12 \%$ in dialysis, and $24 \%$ in heparin-agarose affinity chromatography.

The results of RIA of the two fractions for apoA-I, apo-II, and apoE are shown in Table III. ApoE accounted for a mean of $79.4 \%$ of the protein mass of the apoE-rich fractions, while apoA-I accounted for a mean of $76.2 \%$ of the protein mass of the apoE-poor fractions.

The percentage of apoE that might be covalently bound to apoA-II in an apoE-apoA-II complex was estimated by two different methods (Table IV). Method 1 assumed that all of the apoA-II present in the apoErich $\mathrm{HDL}_{2}$ was involved in an apoE-apoA-II complex. The concentration of apoE present in the apoE-apoAII complex was then calculated as the concentration of the apoE that could be bound by the measured amount of apoA-II, i.e., molar concentration of apoAII as monomer per molar concentration of apoE. Method 2 for estimating the fraction of apoE in the apoE-apoA-II complex was densitometric scanning of stained SDS polyacrylamide gels of the two fractions. Fig. 2, gel 3 demonstrates the pattern generated by

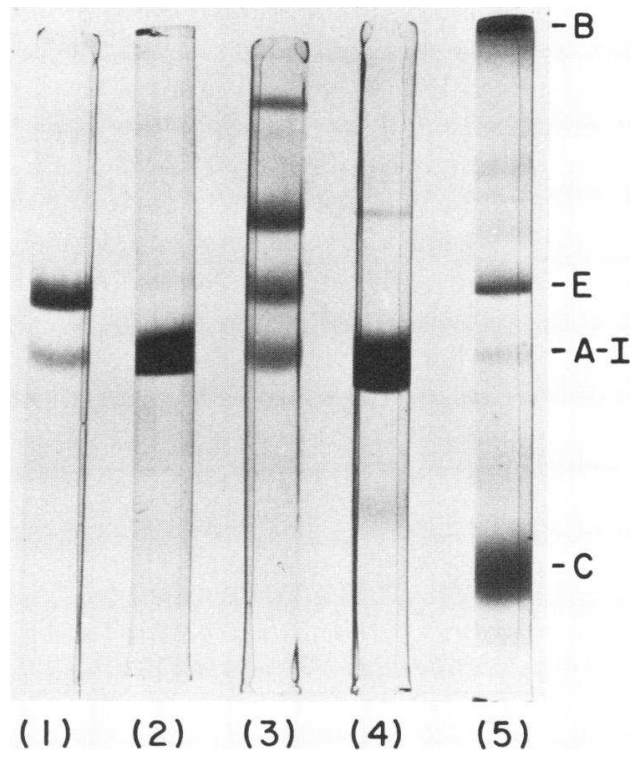

FIGURE 2 SDS gels of apoE-rich and apoE-poor fractions of $\mathrm{HDL}_{2}(d<1.125 \mathrm{~g} / \mathrm{ml})$ from patient 2 . Gels 1 and 3 : apoE-rich $\mathrm{HDL}_{2}$; gels 2 and 4: apoE-poor $\mathrm{HDL}_{2}$. Gels 1,2 and 5 were run after samples had been incubated for $30 \mathrm{~min}$ in $1 \% \beta$-mercaptoethanol; gels 3 and 4 were run in the absence of reducing agents. Gel 5 shows the apoproteins of normal human plasma chylomicrons to indicate the mobilities of apoB, apoE, apoA-I, and the $\mathrm{C}$ apoproteins. 
TABLE III

Percent Apoprotein Composition of $\mathrm{HDL}_{2}$ Subfractions

\begin{tabular}{lllcr}
\hline & & ApoA-I & ApoA-II & ApoE \\
\hline \multirow{2}{*}{ 'Patient 2 } & ApoE-rich & 16.7 & 6.9 & 76.4 \\
& ApoE-poor & 77.9 & 19.7 & 2.4 \\
'Patient 2 & ApoE-rich & 12.2 & 7.9 & 79.9 \\
& ApoE-poor & 80.9 & 16.5 & 2.6 \\
Patient 3 & ApoE-rich & 12.9 & 5.1 & 82.0 \\
& ApoE-poor & 79.7 & 18.0 & 2.3 \\
Patient 4 & ApoE-rich & 13.1 & 13.4 & 73.5 \\
& ApoE-poor & 66.6 & 29.9 & 3.5 \\
Patient 6 & ApoE-rich & 10.3 & 6.2 & 83.5 \\
& ApoE-poor & 79.1 & 15.1 & 5.8 \\
\hline \multirow{2}{*}{ Mean \pm SD } & ApoE-rich & $12.6 \pm 2.1$ & $8.0 \pm 3.7$ & $79.4 \pm 4.5$ \\
& ApoE-poor & $76.2 \pm 6.4$ & $20.3 \pm 6.6$ & $3.5 \pm 1.6$ \\
\hline
\end{tabular}

- $\mathrm{HDL}_{2}$ subfractions from patient 2 were isolated and characterized on two different occasions. Data from the first isolate area presented first, data from the second isolate are presented second. The averages of first and second isolate values from patient 2 were used in calculating the overall means.

SDS gel electrophoresis of apoE-rich $\mathrm{HDL}_{2}$ without exposure of the sample to reducing agents. The clearly visible bands correspond to apoA-I, apoE, and proteins with apparent molecular mass of 45,500 and 67,100 daltons. Since the 45,500- and the 67,100-dalton bands disappear with a concurrent increase in the relative intensity of the apoE band on treatment of the samples with $\beta$-mercaptoethanol (Fig. 2, gel 1), these two bands are felt to represent apoE-apoA-II and apoE-apoE disulfide dimers, respectively. Their apparent molecular mass is consistent with this interpretation. Lower molecular mass proteins are poorly visualized in the $6 \%$ SDS gel system we used; this accounts for the absence of a visible band of apoA-II monomer in gel 1 .

Estimates of the percent of apoE in the apoE-apoAII complex by method 1 and by method 2 suggest that about one-third of apoE is bound covalently to apoA-

TABLE IV

Estimates of Percent Distribution of Plasma ApoE in ApoE-ApoA-II Complex

\begin{tabular}{lcc}
\hline & Method 1 & Method 2 \\
\hline Patient 2 & 37 & 43 \\
Patient 3 & 26 & 42 \\
Patient 6 & 31 & - \\
\hline
\end{tabular}

Method 1 is based on the apoprotein composition of apoE-rich $\mathrm{HDL}_{2}$ as measured by RIA. Method 2 is based on densitometric scanning of stained SDS polyacrylamide gels. See text for details.
II. Method 2 further suggested that a somewhat smaller fraction of plasma apoE was present in an apoE-apoE disulfide dimer ( $30 \%$ for patient $2,27 \%$ for patient 3 ). Thus, both methods agree that only a limited amount of apoE may be present in an apoE-apoA-II complex.

The apoE-rich and apoE-poor fractions of $\mathrm{HDL}_{2}$ from patients 2,3 , and 6 were analyzed by negativestain electron microscopy (Fig. 3). The apoE-rich $\mathrm{HDL}_{2}$ were in each case of larger mean particle diameter $(141 \pm 7 \AA)$ than the apoE-poor $\mathrm{HDL}_{2}(115 \pm 15$ $\AA)$. Both fractions contained a predominant population of spherical or nearly spherical particles. The apoErich $\mathrm{HDL}_{2}$ demonstrated a tendency to aggregate, which resulted in a packing artifact of apparently square-shaped particles. This phenomenon was independent of the temperature of fixation, being evident when samples were fixed at room temperature or at $45^{\circ} \mathrm{C}$, i.e., below or above the cholesteryl ester transition temperature. Square-shaped lipoproteins were, however, not seen in very dilute samples where only free standing particles were present.

The total cholesterol/protein ratio of apoE-rich $\mathrm{HDL}_{2}(1.01 \pm 0.11)$ was higher than that of apoE-poor $\mathrm{HDL}_{2}(0.63 \pm 0.14)$. Percent distribution of the lipid components in apoE-rich $\mathrm{HDL}_{2}$ was $23 \%$ cholesterol, $32 \%$ cholesteryl ester, and $45 \%$ phospholipid. In apoEpoor $\mathrm{HDL}_{2}$ it was $21 \%$ cholesterol, $44 \%$ cholesteryl ester, and $35 \%$ phospholipid. Triglyceride was not detected in any fraction.

Studies of LDL receptor binding activity and regulation of HMG CoA reductase. The ability of 

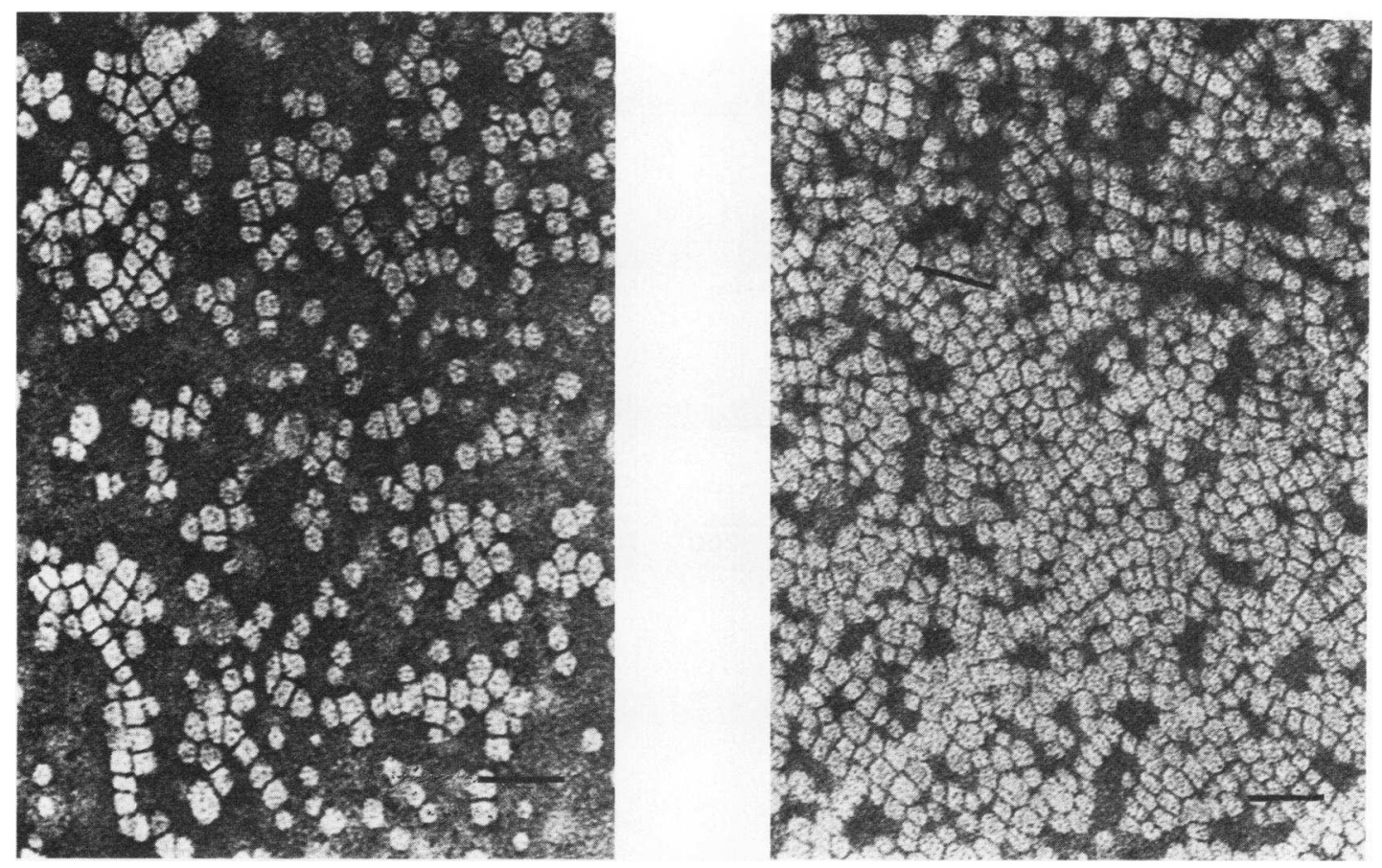

Figure 3 Negative stain electron micrographs of apoE-rich (left) and apoE-poor (right) $\mathrm{HDL}_{2}$ from patient 2 . The bar is equivalent to $500 \AA$.

plasma and lipoprotein fractions from three patients (No. 6-8) to compete with ${ }^{125} \mathrm{I}-\mathrm{LDL}$ in binding to LDL receptors was assessed. Figs. 4 and 5 give results from

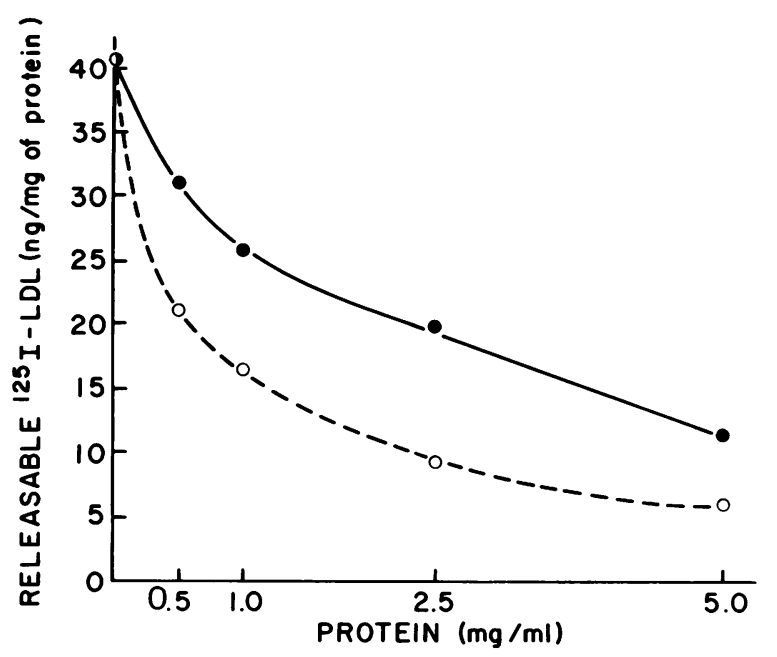

FIGURE 4 LDL receptor binding activity of plasma. The ability of the indicated quantities of plasma (given on the abscissa as amount of added plasma protein) from a patient with abetalipoproteinemia ( $)$ and from a normal volunteer (O) to inhibit the binding of ${ }^{125} \mathrm{I}-\mathrm{LDL}$ to cultured human fibroblasts is shown. Specific binding of labeled LDL is plotted against the ordinate as nanograms of labeled LDL per milligram of cellular protein. patient 8. Similar results were obtained from the other two patients studied. Fig. 4 demonstrates that whole plasma from patient 8 could inhibit the binding of ${ }^{125} \mathrm{I}$ LDL to cultured human fibroblasts, although with somewhat less potency than could normal plasma. On a protein basis, normal plasma had $\sim 1.4$ times the potency of plasma from patient 6 and $\sim$ four times the potency of plasma from patient 8. (Data on plasma are not available for patient 7 because of accidental loss of a sample.)

The ability of lipoproteins to compete with ${ }^{125}$ I-LDL in binding to fibroblasts is illustrated in Fig. 5. $\mathrm{HDL}_{2}$ $(d=1.063-1.125 \mathrm{~g} / \mathrm{ml})$ from patient $8 \mathrm{had}$ a binding potency intermediate between that of normal $\mathrm{HDL}_{2}$ and normal LDL $(d=1.019-1.050 \mathrm{~g} / \mathrm{ml})$ when concentrations were expressed as total protein in the lipoprotein fractions (Fig. 5, panel A). HDL from patients 6 and 7 had even greater potency relative to LDL or normal HDL when the data were expressed in this manner. However, the difference between HDL from patient 8 and HDL from a normal volunteer disappeared when the lipoprotein concentrations were expressed as the amount of the apoE present (Fig. 5, panel B). Studies of the lipoproteins of patients 6 and 7 yielded similar results. These data support the hypothesis that all of the LDL receptor binding activity of HDL resides in the small subset of HDL particles containing apoE. 

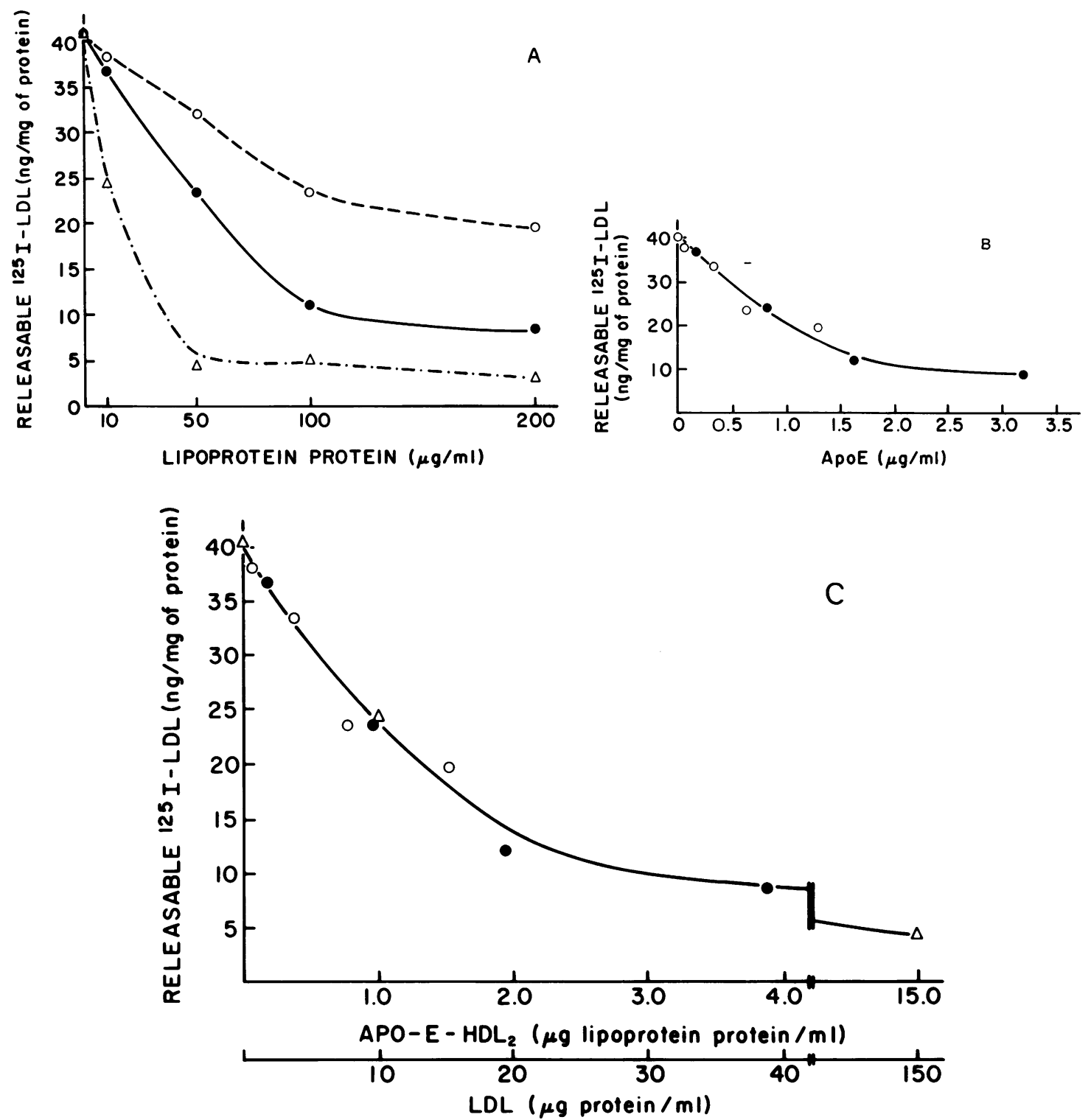

Figure 5 LDL receptor binding activity of lipoproteins. The data from this experiment are expressed in three different ways. In each case, the ordinate indicates specific binding of ${ }^{125} \mathrm{I}$ LDL, expressed as nanograms of labeled LDL bound per milligram of cellular protein. In panel $A$, the abscissa indicates the total protein content of the lipoprotein fractions included in the incubations. In panel $\mathrm{B}$, the concentrations of normal $\mathrm{HDL}_{2}(\mathrm{O})$ and $\mathrm{HDL}_{2}$ from patient 8 $(\bullet)$ are expressed in terms of their apoE content. For panel $\mathrm{C}$, the total protein content of the apoE-rich subfraction of the total $\mathrm{HDL}_{2}$ fractions is calculated as the apoE concentration divided by 0.806 , since a mean of $80.6 \%$ of the protein in apoE-rich $\mathrm{HDL}_{2}$ was found to be apoE. ApoE-rich $\mathrm{HDL}_{2}$ from a normal volunteer $(\mathrm{O})$ and from patient $8(\Theta)$ are compared with normal LDL $(\Delta)$ in their ability to compete with ${ }^{125}$ I-LDL for specific binding on fibroblasts.

Fig. 5, panel $\mathrm{C}$, expresses in a different manner the data from this experiment in which $\mathrm{HDL}_{2}$ and LDL were allowed to compete with ${ }^{125}$ I-LDL in binding to fibroblasts. On the basis of our measurements indicating that a mean of $79.4 \%$ of protein in apoErich $\mathrm{HDL}_{2}$ is apoE, we can calculate the total protein concentration of apoE-rich $\mathrm{HDL}_{2}$ in a solution of unfractionated $\mathrm{HDL}_{2}$ as the apoE concentration divided 
by 0.794 . This calculated concentration of the protein in apoE-rich $\mathrm{HDL}_{2}$ particles is plotted on the abscissa. For normal LDL, the protein concentration determined by the method of Lowry et al. (20) is plotted on another scale on the abscissa. In comparing the relative binding activities of apoE-rich HDL and normal LDL on this plot, it can be seen that any given concentration of apoE-rich $\mathrm{HDL}_{2}$ from patient $8 \mathrm{had}$, on a protein basis, equivalent binding activity to 10 times that concentration of normal LDL. Thus, apoE-rich $\mathrm{HDL}_{2}$ from patient 8 had 10 times the potency of normal LDL for binding to LDL receptors of cultured human fibroblasts. ApoE-rich $\mathrm{HDL}_{2}$ from patients 6 and 7 had measured LDL receptor binding potencies of 25 and 11 times that of normal LDL. It is possible, since the apoE-apoA-II dimer does not interact with LDL receptors, that patient-to-patient variation in receptor binding potency of apoE-rich HDL may be due to variation in the fraction of apoE bound to apoA-II.

The experiments described above demonstrated the ability of the patients' $\mathrm{HDL}_{2}$ to compete with normal ${ }^{125}$ I-LDL for binding sites on cultured human fibroblasts; those experiments suggested that it was the apoE-rich subfraction of the patients' $\mathrm{HDL}_{2}$ that contained the LDL receptor binding activity. This suggestion was confirmed in another series of experiments demonstrating specific binding of apoE-rich $\mathrm{HDL}_{2}$ to fibroblasts (Fig. 6). ApoE-rich and apoE-poor subfractions of $\mathrm{HDL}_{2}$ were isolated from patients 2 and 4. Radioiodinated aliquots of these $\mathrm{HDL}_{2}$ subfractions were then tested for their ability to bind to fibroblasts. At any particular lipoprotein concentration, binding of apoE-rich $\mathrm{HDL}_{2}$ was much greater than was that of apoE-poor $\mathrm{HDL}_{2}$. The binding of apoE-rich $\mathrm{HDL}_{2}$ could be substantially inhibited ( $86 \%$ inhibition) by including $400 \mu \mathrm{g} / \mathrm{ml}$ of normal LDL in the incubation medium, further indicating that this binding involved the LDL receptor. In contrast, $400 \mu \mathrm{g} / \mathrm{ml}$ of LDL produced only 5\% inhibition of the binding of apoE-poor $\mathrm{HDL}_{2}$ to fibroblasts.

An additional series of experiments was performed to demonstrate that the apoE-rich $\mathrm{HDL}_{2}$ of abetalipoproteinemia were not only capable of binding to LDL receptors, but could also effectively suppress HMG CoA reductase activity. ApoE-rich and apoEpoor $\mathrm{HDL}_{2}$ from subjects 2 and 4 were used in these experiments. The data from subject 4 are presented in Fig. 7. The regulatory activity of apoE-rich $\mathrm{HDL}_{2}$ per microgram of lipoprotein protein was $\sim 3.5$ times that of normal LDL and $\sim 20$ times that of the apoEpoor fraction of $\mathrm{HDL}_{2}$ from the same patient. Since apoE accounted for $3.5 \%$ of the protein of the apoEpoor fraction and $73.5 \%$ of the protein in the apoErich fraction from this patient, the difference in reductase-suppressing activity of the two fractions is entirely consistent with the concept that all of that activity resides in the apoE-containing lipoproteins. Similar results were obtained in experiments with the apoE-rich and apoE-poor subfractions of $\mathrm{HDL}_{2}$ from patient 2. There was also a 20-30-fold difference in reductase regulating activity of the two fractions, corresponding to a 20-30-fold difference in the apoE contents of the two subfractions and strongly supporting the concept that the small amount of reductase-regulating activity in the apoE-poor fraction results entirely from small amounts of contamination (3.5\%) with apoE-containing $\mathrm{HDL}_{2}$.

\section{DISCUSSION}

In previous studies of the abnormal lipoproteins of abetalipoproteinemia, Scanu et al. (26) showed that a protein (then unidentified), with mobility similar to that of apoE in SDS polyacrylamide gel electrophoresis, was a prominent component of the patients'
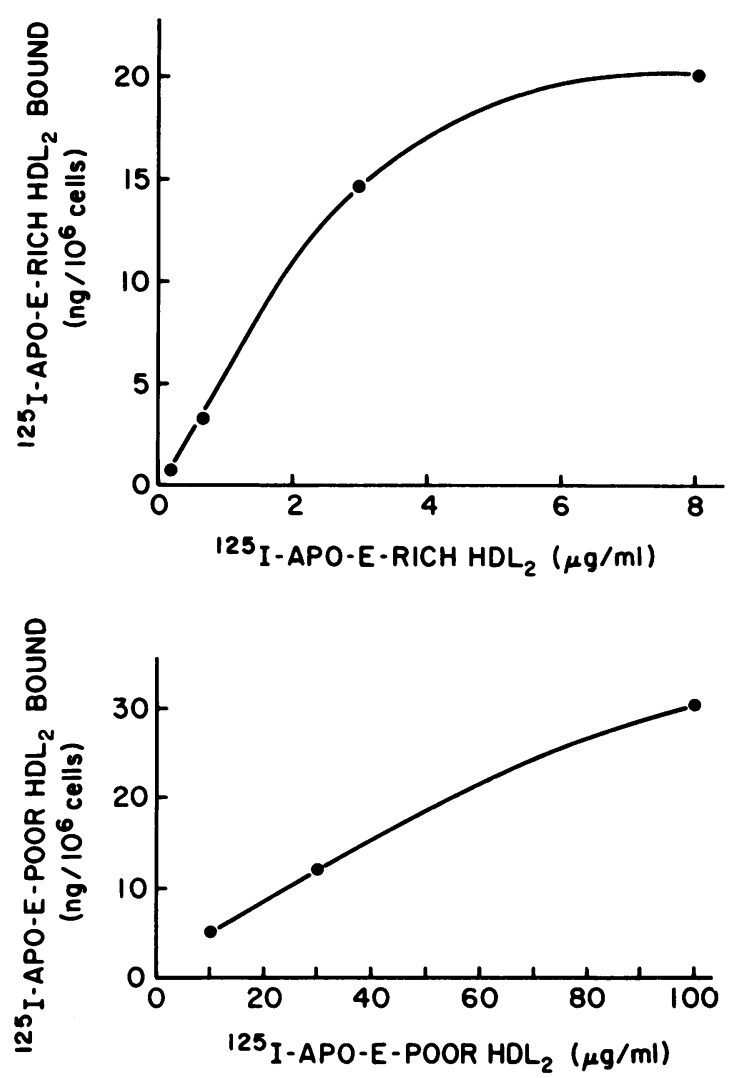

FigurE 6 Binding of radioiodinated $\mathrm{HDL}_{2}$ subfractions to cultured human fibroblasts. Radioiodinated subfractions of $\mathrm{HDL}_{2}$ were incubated with the cells for $5 \mathrm{~h}$ at $37^{\circ} \mathrm{C}$ and then cooled to $4^{\circ} \mathrm{C}$. Cell monolayers were extensively washed, and dextran sulfate releasable radioactivity was measured. Upper panel: binding of ${ }^{125} \mathrm{I}$-apoE-rich $\mathrm{HDL}_{2}$ $(3,585 \mathrm{cpm} / \mathrm{mg})$. Lower panel: binding of ${ }^{125} \mathrm{I}$-apoE-poor $\mathrm{HDL}_{2}(506 \mathrm{cpm} / \mathrm{mg})$.

Apolipoprotein E in Abetalipoproteinemia 


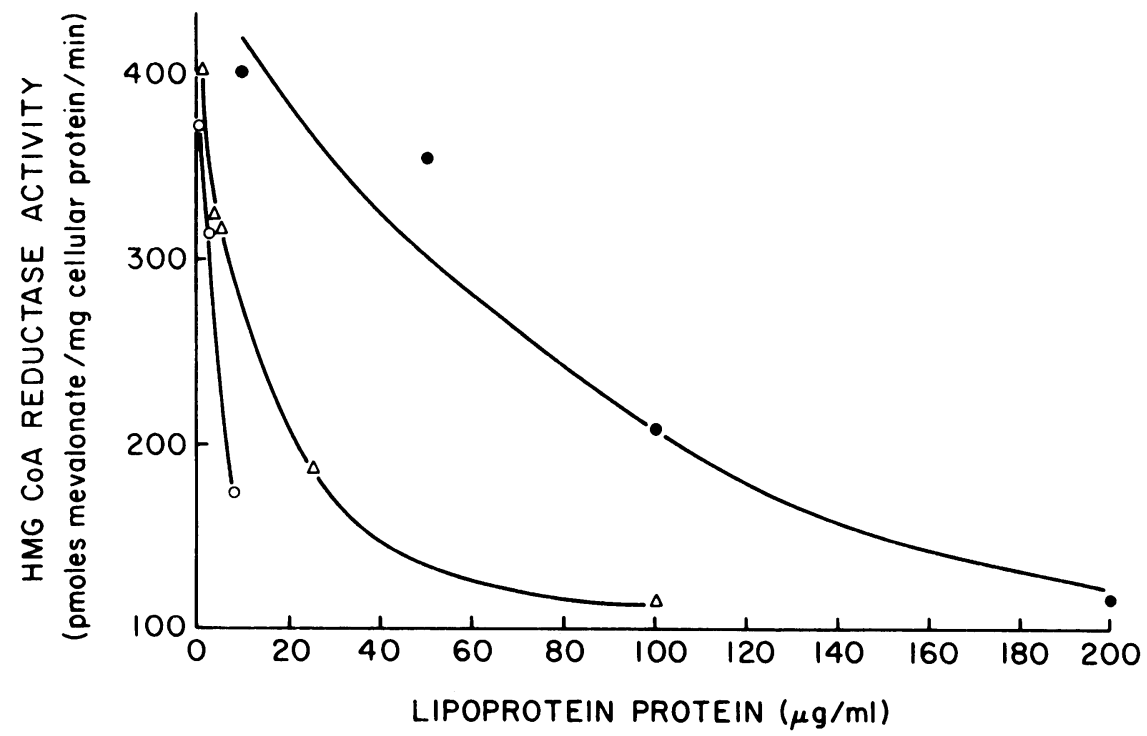

Ficiere 7 Regulation of HMG CoA reductase by apoE-rich and apoE-poor $\mathrm{HDL}_{2}$. The indicated concentrations of apoE-rich $(O)$ and apoE-poor $\left(-H_{2} \mathrm{HL}_{2}\right.$ from patient 4 and of normal $\mathrm{LDL}(\triangle)$ were incubated with monolayers of cultured human fibroblasts for $8 \mathrm{~h}$ at $37^{\circ} \mathrm{C}$. The medium was then removed and the monolayers washed once with iced $0.14 \mathrm{M} \mathrm{NaCl}, 50 \mathrm{mM}$ Tris $\mathrm{HCl}, \mathrm{pH}$ 7.4. The cells were scraped into $1 \mathrm{ml}$ of the same buffer and centrifuged in a Beckman microfuge. The buffer was then aspirated and the cell pellets frozen in liquid $\mathrm{N}_{2}$ until HMG; CoA reductase was measured.

HDL. On the other hand, Illingworth et al. (27) reported that the plasma concentration of apoE in a single patient with abetalipoproteinemia was about half of the mean concentration of a group of normal volunteers. In the present studies, we have found that the mean plasma level of apoE in nine patients with abetalipoproteinemia was slightly higher than the mean plasma level in 50 normal volunteers, but that the concentration of apoE in HDL in abetalipoproteinemia was about twice that of normals. This was a consequence of apoE being distributed between VLDL and HDL in normals, while it is restricted to HDL in abetalipoproteinemia.

When we subfractionated the $\mathrm{HDL}_{2}$ of three patients with abetalipoproteinemia into apoE-rich and apoE-poor fractions, we found that the patients with abetalipoproteinemia demonstrated qualitative similarities to what had been reported in normals $(28,29)$ : the fractions rich in apoE-contained particles of larger mean diameter and higher cholesterol/protein ratio than did those poor in apoE. As had been noted when $H_{D} L_{\lrcorner_{2}}$ was isolated by zonal ultracentrifugation (30), we found that the $\mathrm{HDL}_{2}$ of abetalipoproteinemia was of larger mean particle size than the $\mathrm{HDL}_{2}$ of normal volunteers. We found this to be the case for both subfractions of $\mathrm{HDL}_{2}$ as well as for that entire lipoprotein class when our data on particle diameter for abetalipoproteinemia (apoE-rich HDL $141 \AA$, apoEpoor $\mathrm{HDL}_{2} 115 \AA$ ) were compared with the normative data of Weisgraber and Mahley (28) (apoE-rich HDL $122 \AA$, apoE-poor $\mathrm{HDL}_{2} 95 \AA$ ). Consistent with this, we found higher cholesterol/protein ratios in apoErich $\mathrm{HDL}_{2}$ from the patients than had been reported by Weisgraber and Mahley (28) or by Marcel et al. (29) for the corresponding subfractions of normal $\mathrm{HDL}_{2}$. The apoE-rich $\mathrm{HDL}_{2}$ particles in abetalipoproteinemia have $\sim 1.5$ times the volume of apoE-rich $\mathrm{HDL}_{2}$ in normals. Thus, cellular cholesterol delivery per bound apoE-rich $\mathrm{HDL}_{2}$ particle in abetalipoproteinemia can be expected to be 1.5 times that in normals.

Because of the report that the apoE-apoA-II disulfide dimer does not interact with LDL receptors (31), it was of interest that in the apoE-rich $\mathrm{HDL}_{2}$ about one-third of apoE was in monomeric form, about onethird was in an apoE-ApoA-II dimer, and about onethird was in an apoE-apoE dimer. Our estimates of the amount of apoE-apoA-II dimer present were made with two fundamentally different methods that gave similar results. Method 1 , based on the amount of immunoassayable apoA-II and apoE present in apoE-rich $\mathrm{HDL}_{2}$ should theoretically yield an upper bound for the amount of apoE-apoA-II dimer present. Method 2 was based on densitometric scanning of stained SDS polyacrylamide gels after electrophoresis of the proteins of apoE-rich $\mathrm{HDL}_{2}$. Since the sulfhydryl-binding reagent $p$-chloromercuriphenylsulfonate had been added to these samples immediately after venipunc- 
ture, it is to be expected that there was no in vitro formation of apoE-apoA-II dimer or of apoE-apoE dimer and that the estimate truly reflected the forms of circulating apoE. Both methods agree that only a limited portion of apoE may be present in the apoEapoA-II dimer in the three patients studied.

In the study of the regulation of cholesterol synthesis in nonhepatic tissues, the case of abetalipoproteinemia has been seen as potentially instructive. It was initially expected that the primacy of the LDL in this regulation would be evidenced by the finding of elevated levels of HMG CoA reductase activity, LDL receptor activity, and cholesterol synthesis in abetalipoproteinemia (3-6). However, after an initial report that plasma from a patient with abetalipoproteinemia did not suppress HMG CoA reductase activity in cultured human fibroblasts (32), all other publications have been at variance with the expected results. Myant, Reichl, and Lloyd (3) have measured whole body cholesterol synthesis in a patient with abetalipoproteinemia by sterol balance techniques as $15.4 \mathrm{mg} / \mathrm{kg}$ per $\mathrm{d}$, hardly different from their normal value of 14.3 $\mathrm{mg} / \mathrm{kg}$ per d. Using similar methods, Kayden (33) determined the cholesterol synthesis rate to be $15.2 \mathrm{mg} /$ $\mathrm{kg}$ per $\mathrm{d}$ in a patient with abetalipoproteinemia. Although Illingworth et al. $(4,6)$ have reported approximately twice normal rates of cholesterol synthesis in three patients with abetalipoproteinemia, they could completely account for this as compensation for losses due to intestinal malabsorption. Thus, in vivo cholesterol synthesis in abetalipoproteinemia seems to be effectively down regulated despite the complete absence of lipoproteins containing apoB.

Studies of the regulation of cellular lipid metabolism in vitro yield similar conclusions. Reichl, Myant, and Lloyd (5) have reported that LDL receptor activity was completely suppressed in freshly isolated lymphocytes from patients with abetalipoproteinemia. When they measured the synthesis of $C_{27}$ plus $C_{30}$ sterols from $\left[{ }^{14} \mathrm{C}\right]$ acetate in fresh lymphocytes, they found similar rates of incorporation in cells from patients with abetalipoproteinemia and in control cells. In a similar experiment, Ho et al. (7) found a higher rate of incorporation of $\left[{ }^{14} \mathrm{C}\right]$ acetate into cholesterol in fresh lymphocytes from patients with abetalipoproteinemia than in normal lymphocytes, but the rate of incorporation in the patients' fresh cells was only one-third to one-sixth of that found in normal control cells preincubated in lipoprotein-deficient medium, indicating substantial suppression of cholesterol synthesis in abetalipoproteinemia. Thus, studies from all laboratories that have reported relevant data have shown complete or substantial suppression of cholesterol synthesis in abetalipoproteinemia.

Data from the laboratory of Mahley $(8-10,34)$ indicate that apoE-rich HDL may deliver cholesterol to cells in culture by interaction with high affinity cell surface receptors. In a preliminary report, Bersot et al. (35) indicated that an apoE-containing subfraction of the HDL of patients with abetalipoproteinemia can inhibit the binding of ${ }^{125}$ I-L.DI, to cultured human fibroblasts. The experiments described in the present report provide direct evidence that apoE-rich HDL, may regulate lipid metabolism in vivo and can resolve the apparent paradox of a suppressed LDL receptor pathway in the absence of apoB-containing lipoproteins in abetalipoproteinemia. We found that HDL from patients and from normal volunteers were capable of competing with ${ }^{125}$ I-LDL for specific binding sites on the surface of human skin fibroblasts. The extent of this binding was directly related to the apoE concentration in all cases, suggesting that the apoErich subfraction of HDL accounted for the binding.

In the present work, in addition to having demonstrated binding of the apoE-containing lipoproteins of abetalipoproteinemia to LDL receptors, we have provided direct evidence that those lipoproteins participate in the regulatory portion of the LDL receptor pathway. In particular, the apoE-rich $\mathrm{HDI}_{2}$ were potent inhibitors of HMC CoA reductase. This finding is in accord with a large body' of available information indicating that with the exception of specific, very rare abnormalities of lipoprotein internalization (36) or lysosomal hydrolysis (37), bound lipoproteins have effected metabolic regulation whenever studied (e.g., references 2, 7, 9, 38-45). Furthermore, experiments with cells from patients with abetalipoproteinemia indicate the presence of normal mechanisms for internalization of bound lipoproteins and for the subsequent steps in the LDL receptor pathway $(5,38)$.

Thus, there is an abundance of evidence to indicate that valid predictions regarding cholesterol delivery in abetalipoproteinemia can be made on the basis of our data on the receptor binding activity of the patients' lipoproteins and the composition of their lipoproteins. Table $V$ summarizes a calculation of the cho-

TABL.E V

Potential of ApoE-Rich HDL for Cholesterol Delivery in Abetalipoproteinemia

\begin{tabular}{lccc}
\hline & \multicolumn{3}{c}{ Patient no. } \\
\cline { 2 - 4 } & 6 & 7 & 8 \\
\hline $\begin{array}{l}\text { Protein in apoE-rich HDL }(\mu g / m l) \\
\begin{array}{l}\text { Receptor binding potency } \\
\text { (apoE-rich HDL/LDL) }\end{array}\end{array}$ & 51.5 & 60.9 & 69.7 \\
$\begin{array}{c}\text { 'Cholesterol delivery capacity } \\
\text { (equivalent LDL cholesterol } \\
\text { concentration, } m g / d l)\end{array}$ & $25 \times$ & $11 \times$ & $10 \times$ \\
\hline
\end{tabular}

- Represents protein in apoL-rich HDI. $\times$ receptor binding potency $\times$ (cholesterol/protein $)_{\text {apot:rich uDI. }}$. 
lesterol delivering capacity of apoE-rich HDL in three patients with abetalipoproteinemia. The cholesterol delivering capacity is calculated as the protein concentration of apoE-rich HDL, multiplied by the receptor binding potency of apoE-rich HDL relative to LDL, multiplied by the cholesterol/protein ratio of apoE-rich HDL in abetalipoproteinemia. Our data yield a calculated cholesterol-delivering capacity of apoE-rich HDL equivalent to an LDL cholesterol concentration of $50-150 \mathrm{mg} / \mathrm{dl}$. Analogous calculations from experiments on regulation of HMG $\mathrm{CoA}$ reductase in two different patients (No. 2 and 4) yield similar but slightly lower results. The plasma concentrations of apoE-rich HDL were found to be the functional equivalent of $30-40 \mathrm{mg} / \mathrm{dl}$ of LDL cholesterol. Concentrations of $2.0 \mathrm{mg} / \mathrm{dl}$ of LDL cholesterol in tissue culture have been shown to be capable of producing maximal suppression of LDL receptor activity (46). Since tissue interstitial levels of LDL may be $\sim 10 \%$ of plasma levels (47-49), a tissue concentration of 2.0 $\mathrm{mg} / \mathrm{dl}$ might be equivalent to a plasma LDL concentration of $20 \mathrm{mg} / \mathrm{dl}$. This is considerably less than the concentrations of LDL cholesterol, which are the calculated functional equivalents of the concentrations of apoE-rich HDL present in abetalipoproteinemia. Thus, the concentrations of apoE-rich HDL present in abetalipoproteinemia are capable of playing a regulatory role in lipid metabolism in patients with this disease. We conclude that these apoE-rich lipoproteins can account for the suppression of cholesterol synthesis and LDL receptor activity previously observed in abetalipoproteinemia.

\section{ACKNOWLEDGMENTS}

The authors are grateful to Drs. A. Azizi, M. Cooper, G Delpré, and C. C. Roy for referring their patients with abetalipoproteinemia. The authors thank Dr. DeWitt S. Goodman for helpful editorial suggestions, and Eti Butbul and Elana Sharon for technical assistance. The authors wish to thank Mrs. Sylvia Baer and Mrs. Margaret Tripptree for preparation of the manuscript.

This work was supported by grants HDL 21006, 23864 and 22682 from the National Heart, Lung, and Blood Institute, the United States-Israel Binational Science Foundation grant 1901, and the Childrens Nutritional Disease Project Canadian Friends at the Hebrew University.

\section{REFERENCES}

1. Herbert, P. N., A. M. Gotto, and D. S. Fredrickson. 1978. Familial lipoprotein deficiency (abetalipoproteinemia, hypobetalipoproteinemia, and Tangier disease). In The Metabolic Basis of Inherited Disease. J. B. Stanbury, J. B. Wyngaarden, and D. S. Fredrickson, editors. McGraw-Hill Book Co., New York. 4th edition. 544-588.

2. Brown, M. S., and J. L. Goldstein. 1976. Receptor-mediated control of cholesterol metabolism. Science (Wash., DC). 191: 150-154

3. Myant, N. B., D. Reichl, and J. K. Lloyd. 1978. Sterol balance in a patient with abetalipoproteinemia. Atherosclerosis. 29: 509-512.

4. Illingworth, D. R., W. E. Connor, N. R. M. Buist, B. M. Jhaveri, D. S. Lin, and M. P. McMurry. 1979. Sterol balance in abetalipoproteinemia: studies in a patient with homozygous familial hypobetalipoproteinemia. Metab. Clin. Exp. 28: 1152-1160.

5. Reichl, D., N. B. Myant, and J. K. Lloyd. 1978. Surface binding and catabolism of low-density lipoprotein by circulating lymphocytes from patients with abetalipoproteinemia, with observations on sterol synthesis in lymphocytes from one patient. Biochim. Biophys. Acta. 530: 124-131.

6. Illingworth, D. R., W. E. Connor, D. S. Lin, and J. Diliberti. 1980. Lipid metabolism in abetalipoproteinemia: a study of cholesterol absorption and sterol balance in two patients. Gastroenterology. 78: 68-75.

7. Ho, Y. K., J. R. Faust, D. W. Bilheimer, M. S. Brown, and J. L. Goldstein. 1977. Regulation of cholesterol synthesis by low density lipoprotein in isolated human lymphocytes: comparison of cells from normal subjects and patients with abetalipoproteinemia. J. Exp. Med. 145: 1531-1549.

8. Bersot, T. P., R. W. Mahley, M. S. Brown, and J. L. Goldstein. 1976. Interaction of swine lipoproteins with the low density lipoprotein receptor in human fibroblasts. J. Biol. Chem. 251: 2395-2398.

9. Mahley, R. W., and T. L. Innerarity. 1977. Interaction of canine and swine lipoproteins with the low density lipoprotein receptor of fibroblasts as correlated with heparin/manganese precipitability. J. Biol. Chem. 252: 3980-3986.

10. Innerarity, T. L., R. E. Pitas, and R. W. Mahley. 1979. Binding of arginine-rich (E) apoprotein after recombination with phospholipid visicles to the low density lipoprotein receptors of fibroblasts. J. Biol. Chem. 254: 4186-4190.

11. Pitas, R. E., T. L. Innerarity, K. S. Arnold, and R. W. Mahley. 1979. Rate and equilibrium constants for binding of apoE $\mathrm{HDL}_{\mathrm{c}}$ (a cholesterol-induced lipoprotein) and low density lipoproteins to human fibroblasts: evidence for multiple receptor binding of apo-E $\mathrm{HDL}_{\mathrm{c}}$. Proc. Natl. Acad. Sci. USA. 76: 2311-2315.

12. Blum, C. B., R. Deckelbaum, L. Witte, and M. Fainaru. 1980. Apolipoprotein $\mathrm{E}$ in abetalipoproteinemia. Circulation. 62(Part 2): 43

13. Malloy, J. J., J. P. Kane, D. A. Hardman, R. L. Hamilton, and K. B. Dalal. 1981. Normotriglyceridemic abetalipoproteinemia: absence of the B-100 apolipoprotein. $J$. Clin. Invest. 67: 1441-1450.

14. Blum, C. B., L. Aron, and R. Sciacca. 1980. Radioimmunoassay studies of human apolipoprotein E. J. Clin. Invest. 66: 1240-1250.

15. Witte, L. D., and J. Cornicelli. 1980. Platelet-derived growth factor stimulates low density lipoprotein receptor activity in cultured human fibroblasts. Proc. Natl. Acad. Sci. USA. 77: 5962-5966.

16. Goldstein, J. L., S. K. Basu, G. Y. Brunschede, and M. S. Brown. 1976. Release of low density lipoprotein from its cell surface receptor by sulfated glycosaminoglycans. Cell. 7: 85-95.

17. McFarlane, A. S. 1958. Efficient trace-labelling of proteins with iodine. Nature (Lond.). 182: 53.

18. Langer, T., W. Strober, and R. I. Levy. 1972. The metabolism of low density lipoprotein in familial type II hyperlipoproteinemia. J. Clin. Invest. 51:1528-1536.

19. Beg, Z. H., J. A. Stonik, and H. B. Brewer, Jr. 1979. 3- 
Hydroxy-3-methylglutaryl coenzyme A reductase from avian liver. Catalytic properties. Biochim. Biophys. Acta. 572: 83-94

20. Weber, K., and M. Osborn. 1969. The reliability of molecular weight determination by dodecyl sulfate polyacrylamide gel electrophoresis. J. Biol. Chem. 244: 4406-4412

21. Lowry, O. H., N. J. Rosebrough, A. L. Farr, and R. J. Randall. 1951. Protein measurement with the Folin phenol reagent. J. Biol. Chem. 193: 265-275.

22. Chiamori, N., and R. J. Henry. 1959. Study of the ferric chloride method for determination of total cholesterol and cholesterol esters. Am. J. Clin. Pathol. 31: 305-309.

23. Bartlett, G. R. 1959. Phosphorus assay in column chromatography. J. Biol. Chem. 234: 466-468.

24. Technicon Instruments. Total cholesterol procedure N24b. 1964. In Auto-Analyzer Manual. Chauncy, New York. 345.

25. Lipid Research Clinics Program. 1974. Manual of laboratory operations. Lipid and lipoprotein analysis. National Institutes of Health, Department of Health, Education, and Welfare Publication No. (NIH) 75-628. 1: $74-81$

26. Scanu, A. M., L. P. Aggerbeck, A. W. Kruski, C. T. Lim, and H. J. Kayden. 1974. A study of the abnormal lipoproteins in abetalipoproteinemia. J. Clin. Invest. 53: 440-453.

27. Illingworth, D. R., W. E. Connor, and P. Alaupovic 1981. High density lipoprotein metabolism in a patient with abetalipoproteinemia. Ann. Nutr. Metab. 25: 1-10.

28. Weisgraber, K. H., and R. W. Mahley. 1980. Subfraction of human high density lipoproteins by heparin-Sepharose affinity chromatography. J. Lipid Res. 21: 316-325.

29. Marcel, Y. L., C. Vezina, D. Emond, and G. Suzue. 1980 Heterogeneity of human high density lipoprotein: presence of lipoproteins with and without apoE and their roles as substrates for lecithin:cholesterol acyltransferase reaction. Proc. Natl. Acad. Sci. USA. 77: 2969-2973.

30. Deckelbaum, R., S. Eisenberg, Y. Oschry, and C. Blum. 1981. Abnormal high density lipoproteins in abetalipoproteinemia: relevance to normal HDL formation. Arteriosclerosis. 1: 392a.

31. Innerarity, T. L., R. W. Mahley, K. H. Weisgraber, and T. P. Bersot. 1978. Apoprotein (E-A-II) complex of human plasma lipoproteins. II. Receptor binding activity of a high density lipoprotein subfraction modulated by the apo (E-A-II) complex. J. Biol. Chem. 253: 62896295.

32. Brown, M. S., S. E. Dana, and J. L. Goldstein. 1974 Regulation of 3-hydroxy-3-methylglutaryl coenzyme A reductase activity in cultured human fibroblasts. J. Biol. Chem. 249: 789-796

33. Kayden, H. J. 1978. Abetalipoproteinemia: abnormalities of serum lipoproteins. In Protides of the Biological Fluids. H. Peeters, editor. Pergamon Press, Oxford. 271276.

34. Assman, G., B. G. Brown, and R. W. Mahley. 1975. Regulation of 3-hydroxy-3-methylglutaryl coenzyme A reductase activity in cultured swine aortic smooth muscle cells by plasma lipoproteins. Biochemistry. 14: 39964002.

35. Bersot, T. P., T. L. Innerarity, R. E. Pitas, and R. W. Mahley. 1977. High affinity binding to normal fibroblasts of a high-density lipoprotein from abetalipoproteinemic and cholesterol-fed subjects. Circulation. 56(Part 2): 10la
36. Brown, M. S., and J. L. Goldstein. 1976. Analysis of a mutant strain of human fibroblasts with a defect in the internalization of receptor-bound low density lipoprotein. Cell. 9: 663-674.

37. Goldstein, J. L., S. E. Dana, J. R. Faust, A. L. Beaudet, and M. S. Brown. 1975. Role of lysosomal acid lipase in the metabolism of plasma low density lipoprotein: observations in cultured fibroblasts from a patient with cholesterol ester storage disease. J. Biol. Chem. 250: 8487-8495.

38. Stein, O., D. B. Weinstein, Y. Stein, and D. Steinberg. 1976. Binding, internalization, and degradation of low density lipoprotein by normal human fibroblasts and fibroblasts from a case of homozygous familial hypercholesterolemia. Proc. Natl. Acad. Sci. USA. 73: 14-18.

39. Kayden, H. J., L. Hatam, and N. G. Beratis. 1976. Regulation of 3-hydroxy-3-methylglutaryl coenzyme A reductase activity and the esterification of cholesterol in long term lymphoid cell lines. Biochemistry. 15: 521528.

40. Ho, Y. K., M. S. Brown, H. J. Kayden, and J. L. Goldstein 1976. Binding, internalization, and hydrolysis of low density lipoprotein in long-term lymphoid cell lines from a normal subject and a patient with familial hypercholesterolemia. J. Exp. Med. 144: 444-455.

41. Bierman, E. L., and J. J. Albers. 1977. Regulation of LDL receptor activity in cultured human arterial smooth muscle cells. Biochim. Biophys. Acta. 488: 152-160.

42. Kovanen, P., J. R. Faust, M. S. Brown, and J. L. Goldstein. 1979. Low density lipoprotein receptors in bovine adrenal cortex. I. Receptor-mediated uptake of low density lipoprotein and utilization of its cholesterol for steroid synthesis in cultured adrenocortical cells. Endocrinology. 104: 599-609.

43. Guertler, L. S., and R. W. St. Clair. 1980. Low density lipoprotein receptor activity on skin fibroblasts from Rhesus monkeys with diet-induced or spontaneous hypercholesterolemia. J. Biol. Chem. 255: 92-99.

44. Goldstein, J. L., Y. K. Ho, M. S. Brown, T. L. Innerarity, and R. W. Mahley. 1980. Cholesteryl ester accumulation in macrophages resulting from receptor-mediated uptake and degradation of hypercholesterolemic canine $\beta$-very low density lipoproteins. J. Biol. Chem. 255: 1839-1848.

45. Goldstein, J. L., Y. K. Ho, S. K. Basu, and M. S. Brown. 1979. Binding site on macrophages that mediates uptake and degradation of acetylated low density lipoprotein, producing massive cholesterol deposition. Proc. Natl. Acad. Sci. USA. 76: 333-337.

46. Brown, M. S., and J. L. Goldstein. 1975. Regulation of the activity of the LDL receptor in human fibroblasts. Cell. 6: $307-316$.

47. Reichl, D., L. A. Simons, N. B. Myant, J. J. Pflug, and G. L. Mills. 1973. Lipids and lipoproteins of human peripheral lymph, with observations on the transport of cholesterol from plasma and tissues to lymph. Clin. Sci. Mol. Med. 45: 313-329.

48. Reichl, D., N. B. Myant, and J. J. Pflug. 1977. Concentration of lipoproteins containing apolipoprotein B in human peripheral lymph. Biochim. Biophys. Acta. 489: 98-105.

49. Reichl, D., N. B. Myant, M. S. Brown, and J. L. Goldstein. 1978. Biologically active low density lipoprotein in human peripheral lymph. J. Clin. Invest. 61: 64-71. 